\title{
Field Study of the Impact of Supplementation with Probiotic Yeast (Saccharomyces cerevisiae Sc47-CNCM I-4407) on Reproductive Performance in Dairy Cows
}

\author{
Christine Julien" ${ }^{*}$, Maxime Briche¹, Héloïse Legendre ${ }^{1}$, Vincent Delcloy², Gérard Heumez ${ }^{2}$ \\ ${ }^{1}$ Phileo Lesaffre Animal Care, Marcq-en-Baroeul, France \\ ${ }^{2}$ Gènes Diffusion, Douai, France \\ Email: ${ }^{*}$.julien@phileo.lesaffre.com
}

How to cite this paper: Julien, C., Briche, M., Legendre, H., Delcloy, V. and Heumez, G. (2018) Field Study of the Impact of Supplementation with Probiotic Yeast (Saccharomyces cerevisiae Sc47-CNCM I-4407) on Reproductive Performance in Dairy Cows. Agricultural Sciences, 9, 1664-1676.

https://doi.org/10.4236/as.2018.912116

Received: December 1, 2018

Accepted: December 26, 2018

Published: December 29, 2018

Copyright $(0) 2018$ by authors and Scientific Research Publishing Inc. This work is licensed under the Creative Commons Attribution International License (CC BY 4.0).

http://creativecommons.org/licenses/by/4.0/

\begin{abstract}
Probiotic yeasts are used widely today in the diets of dairy cows with a high production potential. Various studies have researched the effects of live yeasts, in particular Saccharomyces cerevisiae, on digestion, metabolism and performance in dairy cows. The present study aims at evaluating the beneficial effects of using probiotic yeast in dairy cattle farms as a means of improving the breeding performance of milking cows. A group of 14 dairy cattle farms, with at least 40 dairy cows, was selected for the study, all of them using artificial insemination (AI) and that had not used probiotics in the two milking years preceding the study. On these farms, the lactating cows received probiotic yeast supplementation $\left(5 \mathrm{~g} / \mathrm{cow} / \mathrm{day}\right.$, Actisaf ${ }^{\mathbb{R}}$, Saccharomyces cerevisiae Sc47-CNCM I-4407, $1.10^{10} \mathrm{CFU} / \mathrm{g}$, Phileo Lesaffre Animal Care, Marcq-en-Baroeul, France) over 13 months including a 4-week period of adaptation to the product and then the observation period lasting a full year. The analysis was therefore based on 2421 Holstein females inseminated with a total of 4230 doses of conventional Holstein semen at 14 farms over three consecutive years: the period of observation and the two preceding years stated as reference period. Use of daily supplementation with probiotic yeast resulted in a significant improvement of 4 points on average in the success rate of artificial insemination and of 5 points in the success rate of first artificial insemination in multiparous dairy cows. The number of inseminations required to obtain a pregnancy was therefore reduced from 3.1 in the reference period to 2.7 in the probiotic yeast supplementation period $(\mathrm{p}=0.007)$. In parallel, the fat and protein yield by these same animals tended to improve $(+5 \%, \mathrm{p}=0.07)$ between these two periods, demonstrating that it is possible
\end{abstract}


to combine milk performance and maintenance of an effective reproductive system.

\section{Keywords}

Probiotic Yeast, Dairy Cows, Reproduction

\section{Introduction}

Agriculture, and in particular farming of ruminants, is today raising not only serious challenges for society in terms of the environment and animal welfare, but also challenges to keep farming economic. The balance between productivity, quality and economic viability is constantly shifting. Farmers need to set objectives with this in mind in order to guide the strategic and therefore technical choices used when running their farms. At the herd level, the farmer will first and foremost want to manage their diet to the best possible effect, which must be optimized for ruminants. This approach is effective in improving and managing production, ensuring much research and development has been carried out in this field.

Production and quality in ruminants are determined by the amount and nature of the products derived from ruminal fermentation. Feeding a ruminant is above all feeding its rumen microflora, which lives in symbiosis with the animal. However, while microbial digestion does take place naturally in the rumen, it is possible to improve the efficiency of this. To optimize this system, there is a need to improve rumen fibrolysis and microbial synthesis, and to reduce ruminal proteolysis and amylolysis to promote the arrival of glucose and proteins in the intestines, where they are digested. By choosing the quality and quantity of the feed introduced into an animal's diet, it is possible to adapt the diet to its needs and to the production objectives set by the farmer. Following ruminant rationing recommendations is one way of optimizing the production system at both the animal and the herd level.

In this context, use of feed additives is a key to supplementary control. In Europe, live yeasts, as probiotics, fall within the regulatory scope of feed additives for ruminants [1]. This microscopic fungus, employed for many years in the baking, brewing and wine industries, has also made its mark in ruminant nutrition.

Such products are generally marketed in viable form and have high levels of living cells $\left(>10^{9} \mathrm{CFU} / \mathrm{g}\right)$. Daily intake of these probiotics has an effect on animal performance; in beef cattle this is reflected by an improvement in body weight [2], and in ADG, while in dairy cows it is primarily the quantity of milk produced [3] [4] [5] fat content [6] that respond positively to live yeast intake. By stabilizing the ruminal $\mathrm{pH}$ in animals fed on diets with a high energy content [7], which can cause ruminal acidosis, live yeast is known to improve feed effi- 
ciency. However, little research has been carried out to date on the consequences on the reproductive performance of dairy cows, even though efficient utilisation of energy and protein from feed is a determining factor in improving the chances of successful reproduction in high-producing dairy cows.

This study will look at the beneficial effects of using live yeast in dairy cattle farms as a means of improving the breeding performance of milking cows.

\section{Materials and Methods}

\subsection{Choice of Farms}

A group of 15 dairy cattle cow farms was chosen for the study. The farms were selected from among farms that are customers of Gènes Diffusion (Douai, France), an animal genetics and reproduction technologies group. The great majority of these farms were therefore already using artificial insemination (AI). Farms with at least 40 dairy cows (at least 47 first AIs or 76 AIs in total over one year) that had not used probiotics in the two milking years preceding the study and located within a $100 \mathrm{~km}$ radius of Douai entered the study on a voluntary basis. The study sample selected resulted in a total of 15 farms spread over the Hauts-de-France region (Figure 1).

\subsection{Study Duration and Observation Period}

The dairy cows at these volunteer farms received probiotic supplementation (5 g/cow/day) with yeast (Actisaf ${ }^{\circledR}$, Saccharomyces cerevisiae Sc47-CNCM I-4407,

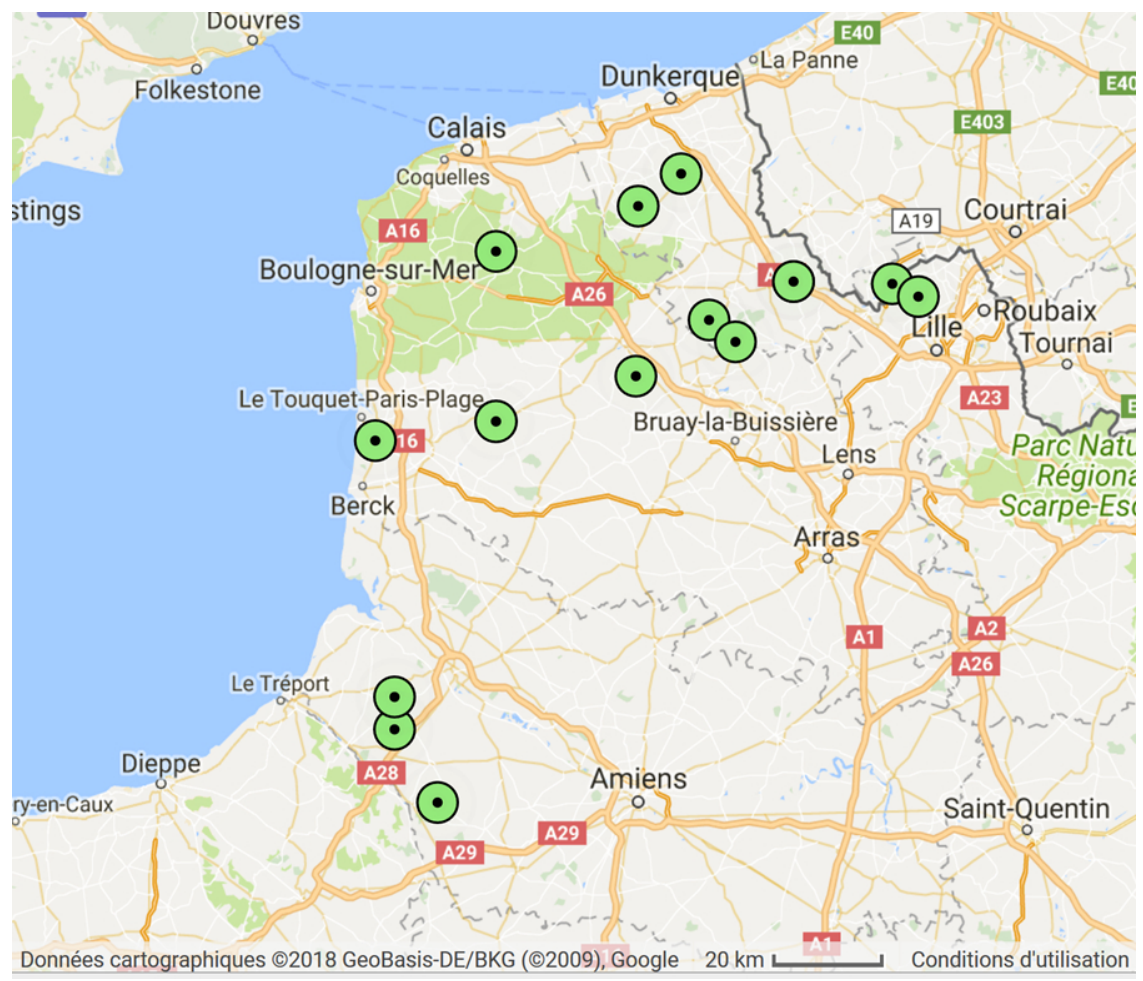

Figure 1. Geographical location of the 15 farms in the study. 
$1.10^{10} \mathrm{CFU} / \mathrm{g}$, Phileo Lesaffre Animal Care, Marcq-en-Baroeul, France) from 1 Sep 2016 to 30 Sep 2017 (observation period) by means of a nutritional feed (Difagri, Saint-Hilaire-de-Loulay, France) included in the animals' daily ration. The distribution period was spread over 13 months. It included:

- A 4-week period of adaptation to the product (the effect of probiotic yeast generally appears in animals after 3 weeks from starting) from 1 Sep 2016 to 30 Sep 2016;

- An observation period from 1 Oct 2016 to 30 Sep 2017, i.e. a full year.

\subsection{Data Collection and Processing}

\subsubsection{Continuously throughout the Observation Period}

Each farm was monitored by an insemination technician twice a month throughout the observation period and by Phileo on 2 visits during the entire period.

\section{1) Product supply}

The amount of product delivered to each farm and the number of dairy cows present at delivery were recorded in order to continuously monitor the correct distribution of the product in terms of quality and quantity throughout the observation year.

\section{2) Feeding of the dairy cow herd}

A quantitative report of the composition of the ration given to lactating cows was established by the farmer with the help of the technicians and engineers in charge of monitoring the field study throughout the observation period.

\section{3) Other information}

All interventions (prophylaxis, hoof trimming, etc.) and changes in farm practices (buildings, milking, monitoring, etc.) were recorded, based on the farmer's declaration.

\subsubsection{At the End of the Observation Period}

\section{1) Reproduction data}

All the reproduction data were extracted from the Gènes Diffusion databases with the agreement of the farms involved in the study from 1 Oct 2016 to 30 Sep 2017.

The raw data were aggregated by farm and by animal:

- Animal data: breed, parity

- Insemination data: date, parity, type of semen (sexed or conventional), breed

- Calving data: date

- Ultrasound gestation control data (if performed at the farm): pregnant cow, date of gestation control

It should be noted that an AI was considered to have resulted in a pregnancy and was therefore considered a pregnant or fertile AI (AIf) if it resulted in calving within the following 270 - 296 days. Alternatively, if no calving was observed over this period, then it was considered an AIf if the female was declared preg- 
nant by ultrasound (from 30 days post-insemination) and confirmed pregnant by palpation at more than 90 days post-insemination.

The data could be used for the individual calculation of:

- Interval of calving to first service (iC-AI1): AI1 date - previous calving date

- Interval of calving to conception (iC-AIf): AIf date - previous calving date

- Number of AI required to achieve an AIf (nAI)

In addition, the criteria listed in Table 1 were calculated on an annual basis for the 15 farms in the study for both categories of animal (primiparous and multiparous).

\section{2) Production data}

Ten herds were enrolled in the individual animal milk recording system over the entire duration of the study, and formed a subsample. The data collected monthly and individually for each of these farms were aggregated:

- Production $(\mathrm{kg} / \mathrm{d})$ : production of the cow recorded at the date closest to the $\mathrm{AI}$ (the performance control most immediately before or after the AI)

- Fat content (FC, g/kg): FC of the milk recorded at the date closest to the AI (the performance control most immediately before or after the AI)

- Protein content (PC, g/kg): PC of the milk recorded at the date closest to the $\mathrm{AI}$ (the performance control most immediately before or after the AI)

- FC/PC ratio: FC/PC of the milk recorded at the date closest to the AI (the performance control most immediately before or after the AI)

- Somatic cell count (SCC, cells $/ \mathrm{mL}$ ): SCC of the female at the date closest to the AI (the performance control most immediately before or after the AI)

The individual data were then averaged by parity (primiparous versus multiparous) on an annual basis and by herd.

\subsection{Description of the Sample Studied}

\subsubsection{Reproduction Data}

The database for individual cows was triaged to keep only the data relating to:

Table 1. Reproduction criteria calculated for each herd.

\begin{tabular}{|c|c|c|}
\hline Criterion & Abbreviations & Formula \\
\hline Fertile AI & AIf & (Total number of AIf/total number of $\mathrm{AI}) \times 100$ \\
\hline Fertile first AI (AI1f) & AI1f & (Number of first AIf/total number of AI1) $\times 100$ \\
\hline $\begin{array}{c}\text { AI rates greater than or } \\
\text { equal to } 3\end{array}$ & $\mathrm{AI} 3$ & $\begin{array}{l}\text { (Number of females with } 3 \text { or more successive AIs }+ \\
\text { number of females with } 2 \text { successive AIs with negative } \\
\text { consecutive ultrasound)/number of females with an } \\
\text { AI1) } \times 100\end{array}$ \\
\hline Interval calving to 1 st $\mathrm{AI}$ & iC-AI1 & Total iC-AI1/number of animals with an AI1 \\
\hline $\begin{array}{l}\text { Interval calving to } \\
\text { conception }\end{array}$ & iC-AIf & Sum iC-AIf/number of animals with an AIf \\
\hline $\begin{array}{c}\text { Number of AIs required } \\
\text { to have an AIf }\end{array}$ & nAI & Total number of AI/number of AIf \\
\hline
\end{tabular}


- primiparous and multiparous females of known Holstein breed (cow breed code $=66$ )

- AIs performed with Holstein semen (breed code $=66$ )

- AIs performed with conventional semen (unsexed)

Note: the data from one farm were removed completely due to a change in management of herd reproduction during the observation period.

Table 2 has taken this into account when presenting the data for each herd (weighted average of the number of AIs performed).

The analysis is therefore based on 2421 Holstein females inseminated with a total of 4230 doses of conventional Holstein semen at 14 farms over 3 consecutive years ( 2 reference years and 1 year of observation, Figure 2).

\subsubsection{Feed Tracking Data}

The composition of the daily ration given to the lactating cows was monitored twice a month, making it possible to define an average ration over the observation period for each of the 15 farms initially selected.

The feeding system was not a criterion for selecting farms. Despite this, it should be noted that most of the farms were generally intensive livestock farms using corn silage ( $77 \%$ of total forage DM on average), beet pulp included as a feed concentrate ( $18 \%$ of total feed concentrate DM) and a little grass forage (hay, grazing, grass silage) (Table 3 ).

\subsection{Data Processing and Analysis}

All the production and reproduction data were collected over a period of 3 years, i.e. 3 successive milking cycles (Figure 2):

- A reference period (Control) from 1 Oct 2014 to 30 Sep 2016; the data from these 2 successive years were averaged to characterize the reference period;

- An observation period (Test) from 1 Oct 2016 to 30 Sep 2017, during which time the cows received supplementation with probiotic yeast.

The daily fat and protein yield was defined as the parameter for evaluating milk production performance in order to take into account both the quantitative and qualitative variations in milk production.

The data collected during the observation and reference periods were processed

Table 2. Description of the reproduction database.

\begin{tabular}{ccccc}
\hline & \multicolumn{2}{c}{ Number of females } & \multicolumn{2}{c}{ Number of AIs } \\
\cline { 2 - 5 } & Multiparous & Primiparous & Multiparous & Primiparous \\
\hline Total sample (15 farms) & 2212 & 1609 & 3920 & 2728 \\
Holstein females & 1549 & 1212 & 2819 & 2094 \\
Holstein semen & 1546 & 1212 & 2816 & 2094 \\
Conventional semen & 1429 & 1058 & 2557 & 1761 \\
14 consistent farms & 1397 & 1024 & 2513 & 1717 \\
\hline
\end{tabular}


Table 3. Description of the average dairy cow ration during the observation period.

\begin{tabular}{ccccccc}
\hline \multirow{2}{*}{ Herd } & \multicolumn{3}{c}{ Daily ration (\% DM) } & \multicolumn{2}{c}{$\begin{array}{c}\text { Corn silage } \\
\text { (\% of forage DM) }\end{array}$} & $\begin{array}{c}\text { Beet pulp } \\
\text { (\% of concentrate DM) }\end{array}$ \\
\cline { 2 - 5 } Forage & Feed concentrate & MVF $^{1}$ & Other $^{2}$ & $82 \%$ & $28 \%$ \\
\hline 1 & $66 \%$ & $32 \%$ & $1 \%$ & $0 \%$ & $77 \%$ & $0 \%$ \\
3 & $79 \%$ & $19 \%$ & $1 \%$ & $1 \%$ & $57 \%$ & $38 \%$ \\
4 & $76 \%$ & $22 \%$ & $1 \%$ & $1 \%$ & $82 \%$ & $0 \%$ \\
5 & $78 \%$ & $20 \%$ & $1 \%$ & $1 \%$ & $74 \%$ & $0 \%$ \\
6 & $70 \%$ & $29 \%$ & $1 \%$ & $0 \%$ & $85 \%$ & $27 \%$ \\
7 & $70 \%$ & $28 \%$ & $1 \%$ & $1 \%$ & $85 \%$ & $21 \%$ \\
8 & $73 \%$ & $25 \%$ & $1 \%$ & $1 \%$ & $68 \%$ & $43 \%$ \\
9 & $56 \%$ & $42 \%$ & $1 \%$ & $0 \%$ & $77 \%$ & $14 \%$ \\
10 & $72 \%$ & $26 \%$ & $2 \%$ & $1 \%$ & $75 \%$ & $2 \%$ \\
11 & $63 \%$ & $36 \%$ & $1 \%$ & $1 \%$ & $77 \%$ & $35 \%$ \\
12 & $75 \%$ & $24 \%$ & $1 \%$ & $0 \%$ & $66 \%$ & $26 \%$ \\
13 & $71 \%$ & $28 \%$ & $1 \%$ & $0 \%$ & $69 \%$ & $27 \%$ \\
14 & $70 \%$ & $28 \%$ & $1 \%$ & $0 \%$ & $90 \%$ & $8 \%$ \\
15 & $76 \%$ & $23 \%$ & $1 \%$ & $0 \%$ & $89 \%$ & $5 \%$ \\
\hline
\end{tabular}

${ }^{1}$ Mineral and vitamin feed; ${ }^{2}$ Sodium bicarbonate or other buffer substance. Note: beet pulp was included as a feed concentrate.

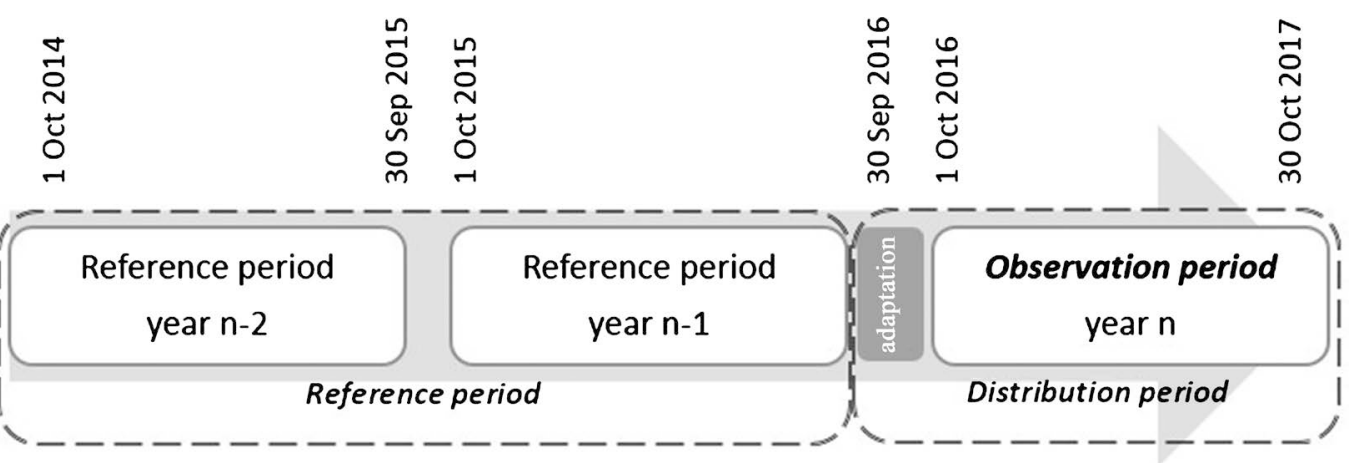

Figure 2. Definition of the chosen analysis periods.

using a mixed model (IBM ${ }^{\circledR}$ SPSS $^{\circledR}$ Statistics ${ }^{\circledR}$, version 23 ) including the fixed effects of the period, the herd and iC-AI1 as a covariate. The farmers received no specific rules on how the cows should be bred after calving, so this covariate took into account the variability of inter-herd practices. The data, expressed as percentages, were converted $(\log 10)$ for analysis.

The results from the multiparous and the primiparous cows were processed separately. Nulliparous cows were not included in the analysis because too many of them did not receive the product during the observation period (impossible to implement distribution). 


\section{Results and Discussion}

Probiotic yeasts, in the form of feed additives for animals, are used widely today in the diets of dairy cows with a high production potential [8]. Various studies conducted within the international scientific community have researched the effects of live yeasts, in particular Saccharomyces cerevisiae, on digestion, metabolism and performance in dairy cows. Generally speaking, the live yeast Saccharomyces cerevisiae increases milk production by $1.2 \mathrm{~kg} /$ cow/day on average, as shown by the meta-analysis conducted by Desnoyers et al. [6]. In addition, Salvati et al. [4] have demonstrated under heat stress conditions the beneficial effects of supplementation with live yeast in terms of more effectively controlling an animal's homeothermy and hence maintenance of milk production.

This improvement in the performance of animals receiving live yeast is explained mainly by the animal's ability to use feed more effectively: Julien et al. [9] have observed an increase of between 0.8 and 3.7 points in the digestibility of total organic matter in lactating dairy cows receiving probiotic yeast supplementation. Regarding fibre degradation, Marden et al. [7] have reported that probiotic yeast supplementation in dairy cows with digestive disorders such as subclinical ruminal acidosis significantly increased total fibre digestibility from $29.6 \%$ to $41.6 \%$. An improvement in the redox (oxidation-reduction potential) values in the rumen is in fact observed in high-producing dairy cows receiving an acidogenic diet supplemented with live yeast [7]: $-115 \mathrm{mV}$ for the control diet vs $-149 \mathrm{mV}$ for the supplemented diet. According to Pinloche et al. [10], this improvement in rumen redox values is linked with the activity of the rumen bacteria [11], in particular lactate-utilizing and fibrolytic bacteria. Unlike the buffer substance sodium bicarbonate, adding live yeast actually induces a lower ruminal lactate concentration. The improvement in rumen reducing conditions is thought to promote the activity of strict anaerobic bacteria such as fibrolytic and lactate-utilizing bacteria, as a result of which the fibre in the ration becomes more digestible [12]. In addition, Jiang et al. [13] have confirmed that a certain number of rumen bacterial groups respond to live yeast supplementation, and underline the link between rumen microbial composition and animal performance.

Moreover, although there seems to be a consensus on the nutritional effects and their consequences on milk production, the consequences on breeding performance have yet to be demonstrated. The national analysis of the fertility data of Prim'Holstein livestock (the standard French Holstein) shows that fertility has deteriorated over the past 15 years, although a slight improvement has been observed since 2013 [14]. Everything suggests that farmers' consideration for reproductive indices over the past 5 years has improved reproductive performance in the younger generations of dairy cows. In addition, Chapaux et al. [15] argue that for many years the increase in milk production has been accompanied by a decrease in fertility, the first perhaps being the cause of the second. The author nevertheless emphasizes the fact that reproduction performance depends essen- 
tially on the quality of the management. Use of feed additives for animals in the diets of ruminants may therefore be considered with this in mind.

In fact, in their study of dairy cows during the peripartum period, Julien et al. [16] have demonstrated that the success rate at the first AI is generally better in dairy cows receiving a high dose $\left(10.10^{10}\right.$ to $20.10^{10} \mathrm{CFU} /$ cow/day) of probiotic yeast over the 6 weeks around calving time; better feed efficiency and hence a lower energy deficit when beginning lactation may therefore improve reproductive function in dairy cows. Production and reproduction compete with each other for the animal's energy intake and cannot easily coexist [17], so use of feed additives for animals may help to control environmental parameters, in particular food efficiency, in order to maximise the animal's full genetic potential. The direct and indirect impact of continuous probiotic yeast supplementation in lactating cows therefore required clarification, and it is the subject of this study.

Overall, no major changes were observed over the observation period in the reproductive parameters of primiparous cows (Table 4), although there was a numerical decrease in the percentage of AIs above parity 3, which was also seen in multiparous cows. On the one hand, it may be assumed that the authors were unable to show any evidence of a difference between the periods studied due to the much smaller number of these primiparous cows (Table 2) compared to those that were multiparous. But what would probably make more sense is that living yeast has a stronger effect on reproductive performance in multiparous cows, which produce more milk than primiparous cows. The same trends are

Table 4. Reproductive parameters over the reference and observation periods for primiparous and multiparous cows.

\begin{tabular}{|c|c|c|c|c|c|c|}
\hline & \multirow{2}{*}{$\begin{array}{l}\text { Reference } \\
\text { period }\end{array}$} & \multirow{2}{*}{$\begin{array}{l}\text { Observation } \\
\text { period }\end{array}$} & \multirow{2}{*}{$\begin{array}{l}\text { Standard } \\
\text { error }\end{array}$} & \multicolumn{3}{|c|}{$p$-value } \\
\hline & & & & $\operatorname{cov}$ & herd & period \\
\hline \multicolumn{7}{|l|}{ Primiparous } \\
\hline AIf & $45 \%$ & $42 \%$ & $1.1 \%$ & 0.862 & 0.519 & 0.772 \\
\hline AIlf & $48 \%$ & $40 \%$ & $1.1 \%$ & 0.958 & 0.166 & 0.741 \\
\hline $\mathrm{AI} 3$ & $20 \%$ & $18 \%$ & $1.1 \%$ & 0.243 & 0.119 & 0.446 \\
\hline $\mathrm{nAI}^{*}$ & 2.4 & 2.5 & 0.20 & 0.615 & 0.85 & 0.789 \\
\hline Calving to AIf (d) & 130.4 & 133.9 & 3.02 & 0.000 & 0.011 & 0.441 \\
\hline \multicolumn{7}{|l|}{ Multiparous } \\
\hline AIf & $34 \%$ & $38 \%$ & $1.0 \%$ & 0.333 & 0.112 & 0.014 \\
\hline AIlf & $31 \%$ & $36 \%$ & $1.1 \%$ & 0.084 & 0.107 & 0.011 \\
\hline $\mathrm{AI} 3$ & $25 \%$ & $23 \%$ & $1.1 \%$ & 0.514 & 0.038 & 0.389 \\
\hline $\mathrm{nAI}^{*}$ & 3.1 & 2.7 & 0.14 & 0.487 & 0.097 & 0.007 \\
\hline Calving to AIf (d) & 148.8 & 143.9 & 3.64 & 0.003 & 0.011 & 0.323 \\
\hline
\end{tabular}

*This number takes into account the AIs occurring before and after the reference and observation periods used to define the AIf. 
observed in terms of milk performance (Figure 3). On the other hand, there is an improvement in the AI success rate in multiparous cows of $34 \%$ to $38 \%$ on average (Figure 4). This improvement is linked with an increase in the success rate of the first $\mathrm{AI}$ ( $31 \%$ to $36 \%$ on average, Figure 4 ).

As a result, the number of inseminations required to achieve pregnancy was significantly lower $(\mathrm{p}=0.007)$ when the cows were receiving probiotic yeast compared to the reference period: 3.1 to 2.7 inseminations on average Actisaf ${ }^{R}$ Sc 47 (Figure 5). However, the difference in the calving to conception interval was not statistically significant, despite an observed numerical decrease of about 5 days. At this stage, it is difficult to give the main reason for this improvement (the general condition of the animal or a direct effect of the probiotic yeast).

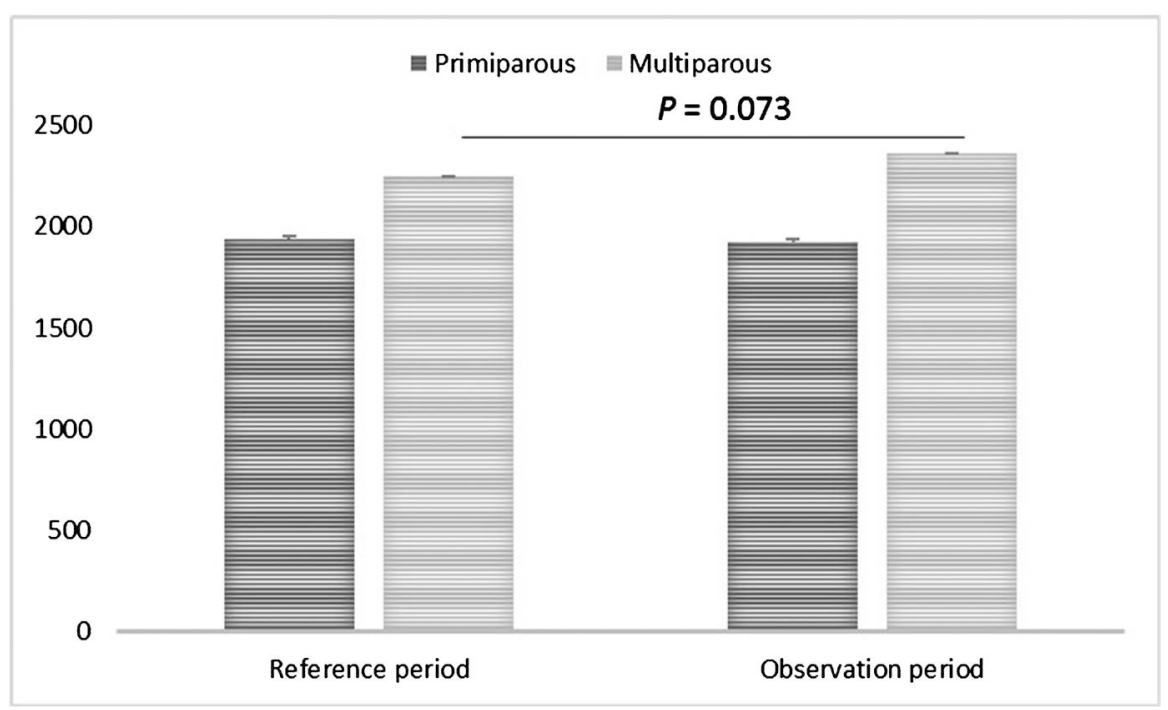

Figure 3. Changes in the average fat and protein yield (g/cow/day) between the reference and observation periods in primiparous and multiparous cows.

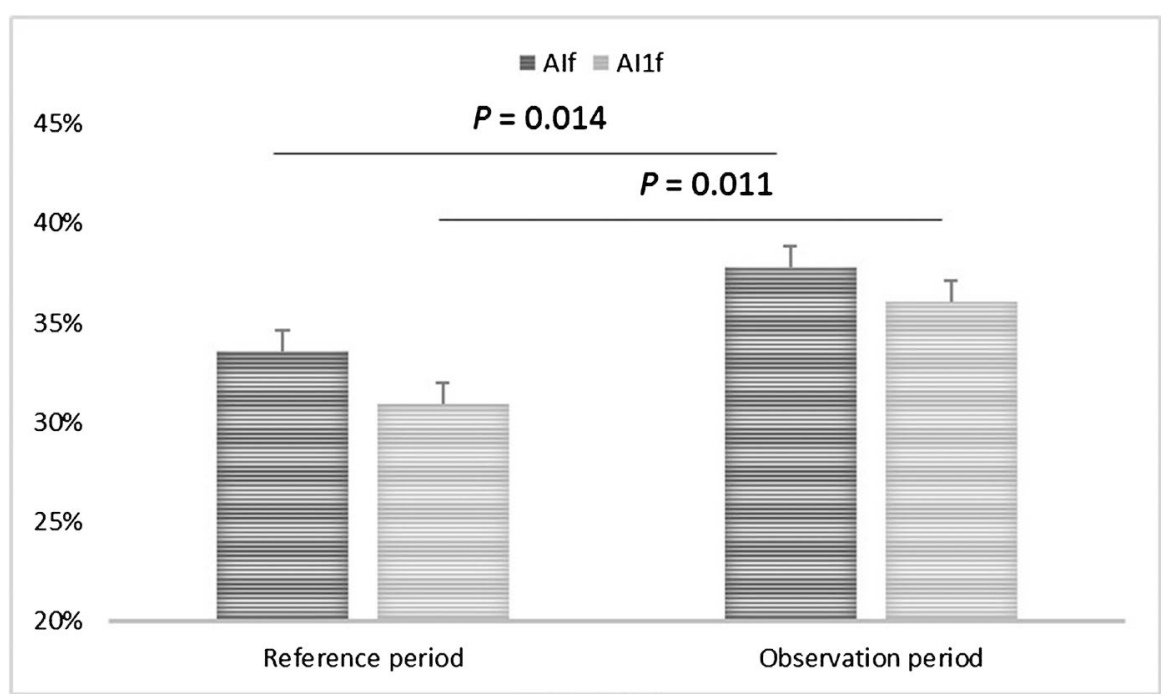

Figure 4. Changes in the fertile AI (AIf) rate and first fertile AI (AI1f) rate between the reference and observation periods in multiparous cows. 


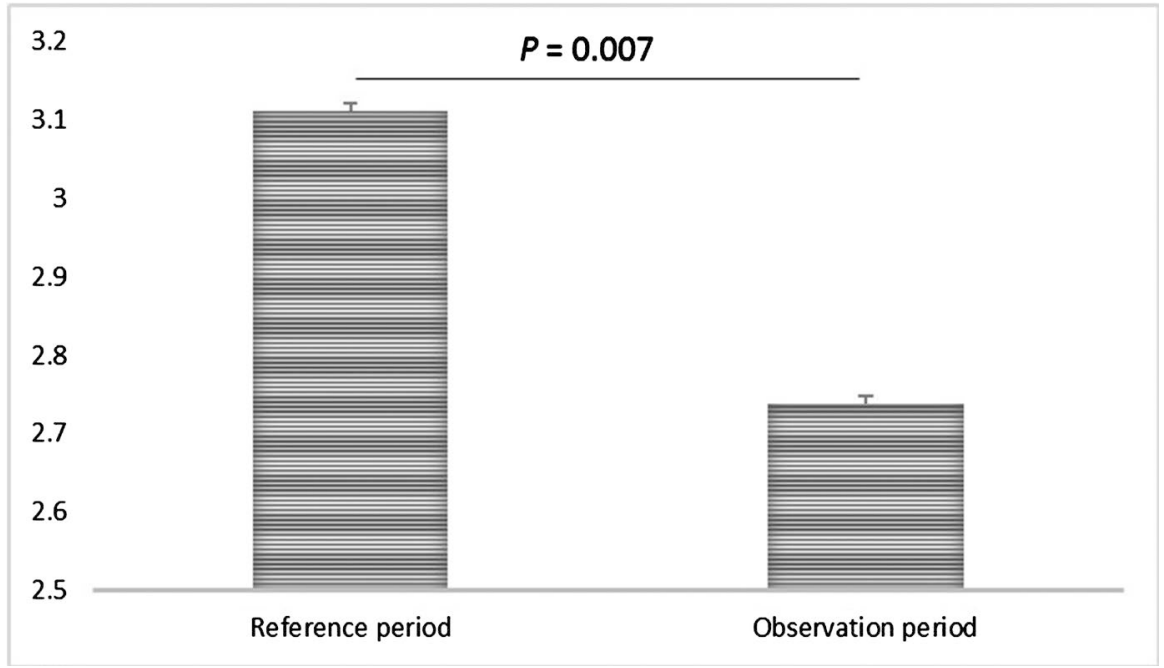

Figure 5. Changes in the number of AIs required for conception between the reference and observation periods in multiparous cows.

Nevertheless, Allbrahim et al. [18] have demonstrated that the preovulatory oestradiol peak and the size of the first ovulatory follicle in early-lactation dairy cows tended to increase following supplementation with Saccharomyces cerevisiae probiotic yeast. Both direct and indirect effects on breeding performance seem conceivable.

In addition, the improved reproductive performance of multiparous animals went hand in hand with a tendency for better production performance (2 246 and $2360 \mathrm{~g} / \mathrm{d}$, Figure 3), which clearly rules out the possibility of the productive function being less demanding on the animal in favour of reproductive function.

\section{Conclusion}

In conclusion, this field study confirms the beneficial effects of optimizing the feed of dairy cows in production in order to improve their reproductive performance. Use of daily supplementation with live yeast at 14 farms over a year resulted in a significant improvement of 4 points on average in the success rate of artificial insemination and of 6 points in the success rate of first artificial insemination in multiparous dairy cows. The number of inseminations required to obtain a pregnancy was therefore reduced from 3.1 in the reference period to 2.7 in the probiotic yeast supplementation period $(p=0.007)$. In parallel, the fat and protein yield by these same animals tended to improve $(+5 \%, \mathrm{p}=0.07)$ between these two periods, demonstrating that it is possible to combine milk performance and maintenance of an effective reproductive system.

\section{Acknowledgements}

The authors would like to thank all the farmers who participated in the study, as well as all the engineers and technicians at Gènes Diffusion and Phileo Lesaffre Animal Care who monitored the trial throughout the observation year. The 
authors also thank Difagri for its financial support during this study.

\section{Conflicts of Interest}

The authors declare no conflicts of interest regarding the publication of this paper.

\section{References}

[1] Commission Regulation (EC) No 1831/2003 of the European Parliament and of the Council of 22 September 2003 on Additives for Use in Animal Nutrition (Text with EEA Relevance). Official Journal of the European Union, 268, 29-43. http://data.europa.eu/eli/reg/2003/1831/oj

[2] Hancock, D.L., Brake, A.C., Montgomery, A.L., Dominey, J.R., Mattingly, C.A. and Cecava, M.J. (1994) Influence of Yeast Addition and Compudose Implantation on Feedlot Performance and Carcass Characteristics of Growing and Finishing Steers. Journal of Animal Science, 72, 300.

[3] Stella, A.V., Paratte, R., Valnegri, L., Cigalino, G., Soncini, G., Chevaux, E., Dell'Orto, V. and Savoini, G. (2007) Effect of Administration of live Saccharomyces cerevisiae on Milk Production, Milk Composition, Blood Metabolites, and Faecal Flora in Early Lactating Dairy Goats. Small Ruminant Research, 67, 7-13. https://doi.org/10.1016/j.smallrumres.2005.08.024

[4] Moallem, U., Lehrer, L., Zachut, M. and Yakoby, S. (2009) The Effects of Live Yeast Supplementation to Dairy Cows during the Hot Season on Production, Feed Efficiency, and Digestibility. Journal of Dairy Science, 92, 343-351. https://doi.org/10.3168/jds.2007-0839

[5] Salvati, G.G., Morais Jr., N.N., Melo, A.C., Vilela, R.R., Cardoso, F.F., Aronovich, M., Pereira, R.A. and Pereira, M.N. (2015) Response of Lactating Cows to Live Yeast Supplementation during Summer. Journal of Dairy Science, 98, 4062-4073. https://doi.org/10.3168/jds.2014-9215

[6] Desnoyers, M., Giger-Reverdin, S., Bertin, G., Duvaux-Ponter, C. and Sauvant D. (2009) Meta-Analysis of the Influence of Saccharomyces cerevisiae Supplementation on Ruminal Parameters and Milk Production of Ruminants. Journal of Dairy Science, 92, 1620-1632. https://doi.org/10.3168/jds.2008-1414

[7] Marden, J.P., Julien, C., Monteils, V., Auclair, E., Moncoulon, R. and Bayourthe, C. (2008) How Does Live Yeast Differ from Sodium Bicarbonate to Stabilize Ruminal $\mathrm{pH}$ in High-Yielding Dairy Cows? Journal of Dairy Science, 91, 3528-3535. https://doi.org/10.3168/jds.2007-0889

[8] Fonty, G. and Chaucheyras-Durand, F. (2006) Effects and Modes of Action of Live Yeasts in the Rumen. Biologia, 61, 741-750. https://doi.org/10.2478/s11756-006-0151-4

[9] Julien, C., Marden, J.P., Auclair, E., Moncoulon, R., Cauquil, L., Peyraud, J.L. and Bayourthe, C. (2015) Interaction between Live Yeast and Dietary Rumen Degradable Protein Level: Effects on Diet Utilization in Early-Lactating Dairy Cows. Agricultural Sciences, 6, 1-13. https://doi.org/10.4236/as.2015.61001

[10] Pinloche, E., McEwan, N., Marden, J.P., Bayourthe, C., Auclair, E. and Newbold, C.J. (2013) The Effects of a Probiotic Yeast on the Bacterial Diversity and Population Structure in the Rumen of Cattle. Plos One, 8, e67824. https://doi.org/10.1371/journal.pone.0067824 
[11] Huang, Y.J., Marden, J.P., Benchaar, C., Julien, C., Auclair, E. and Bayourthe, C. (2017) Quantitative Analysis of the Relationship between Ruminal Redox Potential and $\mathrm{pH}$ in Dairy Cattle: Influence of Dietary Characteristics. Agricultural Sciences, 8, 616-630. https://doi.org/10.4236/as.2017.87047

[12] Marden, J.P. (2007) Contribution à l'étude du mode d'action de la levure Saccharomyces cerevisiae Sc $47 \mathrm{chez}$ le ruminant approche thermodynamique chez la vache laitière. Ph.D. Thesis, Institut National Polytechnique de Toulouse, Toulouse.

[13] Jiang, Y., Ogunade, I.M., Arriola, K.G., Qi, M., Vyas, D., Staples, C.R. and Adesogan, A.T. (2017) Effects of the Dose and Viability of Saccharomyces cerevisiae. 2. Ruminal Fermentation, Performance of Lactating Dairy Cows, and Correlations between Ruminal Bacteria Abundance and Performance Measures. Journal of Dairy Science, 100, 8102-8118. https://doi.org/10.3168/jds.2016-12371

[14] Technipel (2017) Fertilité des vaches laitières c'est mieux: Bilan 1999-2015. Institut de l'élevage, Paris.

[15] Chapaux, P., Glorieux, G. and Hanzen, C. (2004) Des performances de production laitière et de reproduction élevées sont compatibles. Le management en est la clé. Veterinaria, 3, 29-34.

[16] Julien, C., Desmaris, L., Dubois, P., Vagneur, M. and Alves de Oliveira, L. (2017) High Dosage of Live Yeast for Transition Dairy Cows: Nutrition and Health Benefits. Journal of Animal Science, 95, 318-319. https://doi.org/10.2527/asasann.2017.650

[17] Courtheix, P. (2016) Influence de la production laitière sur les performances de reproduction des vaches laitières. DVM Thesis, VetAgro Sup, Lyon.

[18] AlIbrahim, R.M., Crowe, M.A., Duffy, P., O’Grady, L., Beltman, M.E. and Mulligan, F.J. (2010) The Effect of Body Condition at Calving and Supplementation with Saccharomyces cerevisiae on Energy Status and Some Reproductive Parameters in Early Lactation Dairy Cows. Animal Reproduction Science, 121, 63-71.

https://doi.org/10.1016/j.anireprosci.2010.04.183 